\title{
Filsafat Perenialisme dalam Kurikulum Pendidikan Anak Usia Dini
}

\section{Istidamah Nailal Afiyah}

Universitas Islam Negeri Sunan Kalijaga Yogyakarta, Universitas Islam Negeri Sunan Kalijaga Yogyakarta Jl. Marsda Adisucipto, Papringan, Caturtunggal, kec. Depok, Kabupaten Sleman, Daerah Istimewa Yogyakarta 55281

Email: nelanayla64@gmail.com

$$
\text { Naskah diterima: } 24 \text { Juni 2020, direvisi: } 08 \text { September 2020, diterbitkan: } 23 \text { September } 2020
$$

\begin{abstract}
Abstrak
Pendidikan perlu diberikan kepada seseorang sejak usia dini, melalui proses pendidikan ini memberikan kematangan pada generasi muda berupa kematangan dalam berpikir, bertindak dan mengambil keputusan. Kematangan tersebut akan terbentuk melalui proses pendidikan yang berlangsung melalui lingkungan sosialnya yakni d alam keluarga (orang tua), sekolah (pendidik), dan lingkungan masyarakat (teman sebaya). Pendidikan yang diinginkan menurut aliran perenialisme adalah berupa pendidikan yang mencakup dari berbagai aspek dan dimensi ilmu. Filsafat perenialisme merupakan salah satu pemikiran filsafat tentang bagaimana manusia mampu berhadapan dengan perubahan dunia yang begitu pesat sejak lama. Pada aliran filsafat perenialisme menekankan pada nilai baik yang ada pada dalam diri manusia, sehingga akan terbentuk manusia yang kritis dan rasional dalam memikirkan masa depannya karena manusia dilahirkan di dunia ini dalam keadaan fitrah. Filsafat perenialisme dalam kurikulum pendidikan anak usia dini yakni upaya membentuk karakter anak yang bermoral, menjunjung nilai-nilai luhur agama, dan senantiasa menjunjung tinggi nilai-nilai kebaikan diperlukan yang namanya pendidikan. Dalam sebuah pendidikan tentu saja diperlukan kurikulum yang dijadikan sebagai tolok ukur dalam sebuah pembelajaran karena hal tersebut sangatlah penting dan tidak bisa terpisahkan dalam sebuah pembelajaran.
\end{abstract}

Kata Kunci: pendidikan, filsafat, perenialisme, kurikulum PAUD

\author{
Abstract \\ Education needs to be given to someone from an early age, through this educational process provides \\ maturity to the younger generation in the form of maturity in thinking, acting and making decisions. \\ Maturity will be formed through the educational process that takes place through the social environment,
}


namely in the family (parents), schools (educators), and the community (peers). Desired education according to the flow of perennialism is in the form of education that covers various aspects and dimensions of science. The philosophy of perennialism is one of the philosophical thoughts about how humans are able to deal with the changing world so rapidly for so long. In the flow of philosophy perennialism emphasizes the good values that exist in humans, so that bumans will form critical and rational people in thinking about their future because bumans are born in this world in a state of nature. The philosophy of perennialism in the early childhood education curriculum is in an effort to shape the moral character of children, uphold the noble values of religion, and always uphold the values of goodness needed, which is called education. In an education, of course, a curriculum is needed that is used as a benchmark in learning because this is very important and cannot be separated in a lesson

Keywords: education, philosophy, perennialism, PAUD curriculum.

\section{Pendahuluan}

Filsafat dan pendidikan memiliki hubungan yang sangat erat, karena pendidikan hakikatnya merupakan suatu proses pewarisan nilai-nilai filsafat yang dikembangkan untuk memenuhi kebutuhan hidup agar memiliki kehidupan yang lebih baik dari kehidupan sebelumnya. Dalam pendidikan, tentu saja diperlukan filsafat pendidikan, karena filsafat pendidikan adalah ilmu yang mempelajari dan berusaha menyelesaikan masalah-masalah yang muncul dalam dunia pendidikan. Secara filosofis, pendidikan adalah suatu hasil peradaban suatu bangsa yang terus menerus dikembangan berdasarkan cita-cita dan tujuan filsafat serta pandangan hidupnya sehingga menjadi suatu kenyataan yang melembaga di dalam masyarakat (HW, 2013: 127). Dengan demikian muncullah filsafat pendidikan yang digunakan sebagai dasar dalam berfikir, berperasaan, dan berkelakuan yang menentukan bentuk sikap hidupnya.

Pendidikan merupakan bagian kebutuhan mendasar manusia yang harus dipenuhi seperti halnya dengan sandang, pangan, kesehatan, dan tempat tinggal. Pendidikan adalah bagian dari masalah politik yang diartikan sebagai pengelolaan urusan rakyat yang berdasarkan oleh ideologi negara. Berdasarkan pemahaman mendasar ini, politik pendidikan suatu negara sangat ditentukan oleh ideologi yang diemban negara tersebut. Dengan demikian, politik pendidikan dapat dipahami sebagai strategi pendidikan yang dirancang negara dalam upaya menciptakan kualitas human resources (sumber daya manusia) yang dicita-citakan. 
Perenialisme merupakan suatu aliran dalam pendidikan yang lahir pada abad 20 . Perenialisme lahir sebagi suatu reaksi terhdap pendidikan progresif. Perenialisme menentang pandangan proresivisme yang menekankan perubahan dan sesuatu yang baru. Perenialisme memandang bahwa situasi dunia sekarang ini penuh ketidakteraturan, ketidakpastian, dan kekacauan terutama dalam berbagai kehidupan baik moral, intelektual, dan sosio-kultural. Oleh karena itu perlu ada usaha untuk mengamankan ketidakberesan tersebut (Sadulloh, 2007: 151).

Untuk menghasilkan SDM yang berkualitas, tentu saja perlu adanya pendidikan yang memiliki konsep dan landasan yang jelas. Dewasa ini pendidikan kita boleh dikatakan telah berhasil, akan tetapi disisi keberhasilannya tersebut tanpa disadari atau memang kita tidak mau sadar dan memikirkannya bahwa kegagalan besar dalam membentuk karakter anak bangsa. Atau memang pendidikan di negara kita harus kembali sebagaimana pendidikan waktu dulu nenek moyang kita dengan peralatan, perbekalan seadanya namun berhasil dalam membentuk karakter anak bangsa. Maka melalui tulisan singkat ini akan diuraikan sebuah pemikiran perenialisme dalam kurikulum pendidikan anak usia dini, yang mana pengertian pendidikan anak usia dini adalah sebuah pendidikan yang diberikan kepada anak usia 0-6 tahun dengan memberikan rangsangan yang dapat membantu pertumbuhan serta perkembangannya baik jasmani maupun rohani, sehingga sejak usia dini inilah masa yang sangat penting dalam memberikan nilai-nilai moral dan karakter pada anak. Sedangkan pemikiran perenialisme ini hadir dalam pendidikan karena lebih menekankan pada nilai-nilai moral yang harus diajarkan kepada manusia sehingga tidak akan kehilangan arah, dan barangkali dapat menjadi tolok ukur terhadap pendidikan di era sekarang.

\section{Hasil dan Diskusi}

\section{Pengertian Perenialisme dan Sejarah}

Secara etimologis, perenialisme diambil dari kata perennial dengan mendapat tambahan -isme. Perenial berasal dari bahasa Latin yaitu perennis yang kemudian diadopsi ke dalam bahasa Inggris yang berarti kekal, selama-lamanya atau abadi. Sedangkan tambahan -isme di belakang mengandung pengertian aliran atau paham (Hidayat dan Nafis, 2003: 39). Jadi perenialisme dapat didefinisikan sebagai aliran atau paham kekekalan.

Pereniaisme dengan kata dasarnya perenial, yang berarti continuing throughout the whole year atau lasting for a very long time, yakni abadi atau sampai kekal yang terus ada tanpa 
akhir. Dalam pengertiannya yang lebih umum dapat dikatakan bahwa tradisi dipandang juga sebagai prinsip-prinsip yang abadi yang terus mengalir sepanjang sejarah manusia, karena ia adalah anugerah Tuhan pada semua manusia dan memang merupakan hakikat insaniah manusia (Zuhairini, 2001: 27).

Pada aliran perenialisme berupaya menerapkan nilai-nilai atau norma-norma yang bersifat kekal dan abadi yang selalu seperti itu sepanjang sejarah manusia, jadi aliran ini dianggap sebagai suatu aliran yang ingin kembali atau mundur kepada nilai-nilai kebudayaan masa lampau. Maksudnya kembali pada masa lampau menurut aliran ini, bukanlah dalam pengertian bernostalgia dan sekedar mengingat-ingat kembali pola kehidupan masa lalu, tetapi untuk membina kembali keyakinan akan nilai-nilai asasi masa silam untuk menghadapi problematika kehidupan manusia saat sekarang dan bahkan sampai kapan pun dan dimana pun (Syam, 1986: 295-297).

Kondisi dunia modern yang sangat mengandalkan rasionalitas empiris-positivistis yang memandang bahwa kebenaran dalam konteksnya yang serba terukur, teramati dan teruji secara inferensial serta melihat realitas sebagai sesuatu yang serba beracuan dengan materi, juga memunculkan berbagai masalah dalam kemanusiaan seperti munculnya sikap ambivalensi yang mengkhawatirkan dan akan mendatangkan kebimbangan, kecemasan, kebingungan, dan ketakutan dalam bertindak serta bertingkah laku. Sehingga manusia hidup dalam ketidakmenentuan dan cenderung akan kehilangan arah. Pengabaian berpikir logis dalam hal ini juga memunculkan ketidak mampuan manusia melihat pengetahuan sebenarnya. Hal ini mengingat corak kehidupan yang serba rasional bertujuan dengan landasan empiris-positivistis yang melihat realita dunia dengn serba objektif dimana kebenran ilmu berangkat dari fakta-fakta yang terverifikasi dan terukur secara ketat, sehingga menjadikan ilmu pengetahuan dan teknologi sebagai dasar orientasi dalam setiap kehidupan (Muhmidayeli, 2011: 159).

Kondisi diatas, tidak boleh dibiarkan begitu saja, oleh karena itu perlu adanya usaha yang serius untuk menyelamatkan manusia dari kondisi yang mengkhawatirkan dengan cara mencari dan menemukan orientasi dan tujuan yang jelas, dan ini adalah tugas dari filsafat pendidikan. Filsafat perenialis dalam hal ini mengambil jalan regresif yaitu dengan cara mengembalikan arahnya seperti yang telah menjadi prinsip dasar perilaku sebagaimana yang dianut pada abad pertengahan dan masa kuno.

Secara filosofi, filsafat perenialisme memiliki dasar pemikiran yang melekat pada aliran filsafat kuno atau klasik yang ditokohi oleh Aristoteles, Plato, Aquinas dan 
Augustinus. Menurut Sayyed Husein Nasr, istilah filsafat perenialisme ini digunakan pertama kali oleh Augustinus (1497-1548) dalam sebuah karyanya yang berjudul dengan De Perennia Philosophia yang diterbitkan pada tahun 1540 M. Istilah menjadi lebih populer di tangan Leubniz yang digunakan dalam suratnya kepada temannya Remundo yang ditulis pada tahun 1715 M. Dalam konteks pendidikan, perenialisme ditokohi oleh Robert Maynard Hutchins, Mortimer J. Adler dan Sir Richard Livingstone (Syam, 1986: 297).

Prinsip dasar perenialisme kemudian dikembangkan oleh Sayyed Husin Nasr yang mengatakan pendapat bahwa setiap manusia yang lahir memilik fitrah yang sama yakni dengan berpangkal pada asal kejadiannya sebagai manusia yang fitri, yang memiliki konsekuensi logis pada watak kesucian dan kebaikan. Sifat manusia tidak berubah sama sekali karena prinsip-prinsipnya mengandung kontinuitas dalam setiap ruang dan waktu. Menurutnya tradisi yang mengisyaratkan kebenaran yang fitri bersifat langgeng, tetap, abadi dan berkisambungan, sifatnya tidak akan lenyap bersamaan dengan lenyapnya waktu. Menurut Sayyed Husein Nasr, perenialisme dalam konteks ini terlihat seperti ingin mengembalikan kesadaran manusia akan hakikatnya yang fitri dan suci, yang nantinya akan membuatnya memiliki watak kebaikan dan kesucian (Muhmidayeli, 2011: 160).

\section{Landasan Filosofis Perenialisme}

Dasar pemikiran filsafat perenialisme pada perkembangan pemikiran filsafat pada umumnya, dasarnya pun terlihat dari keyakinan ontologis seseorang tentang alam dan manusia. Pada aliran filsafat perenialisme memiliki pandangan bahwa hakikat manusia adalah sebagai makhluk rasional yang akan selalu sama bagi setiap manusia dimana pun mereka berada dan sampai kapan pun dalam pengembangannya untuk dimasa depan. Keyakinan ontologis sedemikian, membawa mereka pada suatu pemikiran, bahwa kemajuan dan keharmonisan yang dialami oleh manusia di suatu masa akan dapat pula diterapkan pada manusia-manusia lain pada masa dan tempat yang berbeda, sehingga kesuksesan masa lalu dapat pula diterapkan untuk memecahkan problem masa sekarang dan akan datang bahkan sampai kapan pun dan dimana pun (Muhmidayeli, 2011: 161).

Aliran perenialisme berkeyakinan bahwa kendatipun dalam lingkungan dan tempat yang berbeda-beda, hakikat manusia tetap menunjukkan kesamaannya. Oleh karena itu, pola dan corak pendidikan yang sama dapat diterapkan kepada siapa pun dan dimana punia berada. Menurutnya, setiap manusia memiliki fungsi kemanusiaan yang sama 
karena memang terlahir dari hakikat yang sama sebagai makhluk rasional. Aliran perenialisme berpendapat, bahwa rasionalitas adalah hukum pertama yang akan tetap benar di segala waktu dan tempat. Dengan prinsip rasionalitas ini pula akan memunculkan adanya prinsip kesadaran dan kebebasan. Aliran ini berkeyakinan bahwa dimana pun manusia tetap menunjukkan kesamaannya. Oleh karena itu apapun pola pendidikan yang diterapkan, seorang manusia akan tetap menerima pendidikan tersebut. Karena kita terlahir sebagai makhluk rasional yang membedakan dengan makhluk lainnya (Siregar, Jurnal Agama dan Ilmu Pengetahuan, 2, Oktober 2016: 83-172).

Para penganut filsafat perenialisme berpendapat bahwa latihan dan pembinaan berpikir (mental disiplin) merupakan bagian yang sangat penting dalam belajar atau keutamaan selama proses pembelajaran. Oleh karena itu teori dan program pendidikan pada umumnya dipusatkan pada pembinaan kemampuan berpikir dan disiplin. Pendidikan dalam teori ini dimaknai dengan suatu aktivitas yang menitikberatkan programnya pada perubahan-perubahan dan perbaikan-perbaikan. Prestasi yang gemilang dari pengembangan ilmu pengetahuan dan teknologi terus diraih oleh manusia di alam modern dan telah menunjuk pada perkembangan tiada tara dalam peradapan manusia. Sebagai salah satu tokoh yang menjadi rujukan aliran ini, Aristoteles mengungkapkan bahwa penekanan dalam melatih dan membiasakan diri merupakan hal yang mendasar bagi pengembangan kualitas manusia. Oleh karena itu, kesadaran disiplin mental seharusnya ditanamkan dan dikembangkan sejak usia dini.

\section{Tokoh-Tokoh Perenialisme}

Secara maknawi teori perenialisme sudah ada sejak zaman filosof abad kuno dan pertengahan. Seperti halnya dalam bidang pendidikan, konsep dari filsafat perenialisme dalam pendidikan dilatarbelakangi oleh filsafat-filsafat plato yang mana diyakini sebagai bapak idealisme klasik, filsafat Aristoteles yang diyakini sebagai bapak realisme klasik, dan filsafat Thomas Aquinas yang mencoba untuk memadukan antara filsafat Aristoteles dengan ajaran filsafat Gereja Katolik yang tumbuh pada zamannya atau pada abad pertengahan (Sadulloh, 2012: 152).

a. Plato

Plato hidup pada zaman kebudayaan yang sarat dengan ketidakpastian, yaitu filsafat sofisme. Ukuran kebenaran dan ukuran moral menurut filsafat sofisme adalah manusia itu sendiri secara pribadi, maksudnya adalah pada zaman itu tidak ada kepastian dalam hal moral dan kebenaran, sehingga tergantung pada masing-masing 
individu itu sendiri. Plato berpandangan bahwa realitas yang hakiki itu tetap tidak berubah karena telah ada pada diri manusia sejak dari asalnya. Esensial realita, ilmu pengetahuan dan nilai-nilai adalah manifestasi dari pada hukum universal yang abadi dan sempurna, yakni ideal. Dengan demikian keterlibatan sosial hanya akan mungkin bila ideal itu menjadi standart, asas normatif dalam tata pemerintahan. Dan tujuan pendidikan adalah membina pemimpin yang sadar dan mempraktekkan asas-asas normatif itu dalam semua aspek kehidupan. Menurut Plato, dunia ideal adalah segala sesuatu yang bersumber dari ide mutlak, yaitu Tuhan. Manusia menemukan kebenaran, pengetahuan, dan nilai moral dengan menggunakan akal atau rasio (Pelu, Jurnal Sejarah dan Pembelajarannya, 2, Juli 2011).

Tujuan utama dari pendidikan adalah membina seseorang agar memiliki sikap yang sadar akan asas normatif dan melaksanakannya dalam segala aspek kehidupan. Masyarakat yang ideal adalah masyarakat adil sejahtera. Manusia yang terbaik adalah manusia yang hidup atas dasar prinsip idea mutlak, yaitu suatu prinsip mutlak yang menjadi sumber realitas semesta dan hakikat kebenaran abadi yang transcendental yang membimbing manusia untuk menemukan apa itu kriteria politik, moral, dan sosial serta keadilan. Ide mutlak adalah Tuhan.

Untuk mengatasi masalah yang dihadapi masyarakat saat ini perlu adanya sesuatu kebijakan pemerintah, pemerintah wajib memberikan pendidikan, fasilitas yang layak untuk anak-anak bangsa. Karena memperbaiki nasib dan masa depan mereka merupakan kewajiban bersama.

b. Aristoteles

Aristoteles adalah murid Plato, namun dalam pemikiran-nya mereaksi terhadap filsafat gurunya, yaitu idealisme. Hasil pemikirannya disebut filsafat realisme. Ia mengajarkan cara berpikir atas prinsip realistis, yang lebih dekat pada alam kehidupan manusia sehari-hari. Sebagaimana ajaran Aristoteles meneruskan ide-ide Plato, tetapi dengan cara yang lebih dekat dengan realitas dunia, dan tidak lebih supernatural dan exstra-natural seperti konsepsi Plato. Aristoteles terutama menitik beratkan pada pembinaan berpikir melalui media sciences dan terutama dengan filsafat tentang pembinaan pemimpin yang bijak dalam rangka tujuan politik dan kehidupan negara, ia sependapat dengan gurunya yaitu Plato.

Aristoteles juga menganggap pembinaan kebiasaan sebagai dasar. Terutama dalam pembinaan kesadaran disiplin atau moral, harus melalui proses permulaan 
dengan kebiasaan pada waktu anak masih usia dini. secara ontologis, ia mengatakan bahwa sifat atau watak anak lebih banyak materi-materi dari pada bentuk, dan ia masih dalam proses "jauh" dan aktualitas. Dengan kata lain, guru lebih banyak mempunyai aktualitas, sedangkan murid lebih banyak potensilitas (Syam, 1986: 321). Aristoteles juga mengungkapkan bahwa manusia adalah makhluk materi dan rohani sekaligus. Sebagai materi, ia menyadari bahwa manusia dalam hidupnya berada dalam kondisi alam materi dan sosial. Sebagai makhluk rohani, manusia sadar ia akan menuju pada proses yang lebih tinggi yang menuju kepada manusia ideal. Perkembangan budi merupakan titik pusat perhatian pendidikan dengan filsafat sebagai alat mencapainya (Pelu, Jurnal Sejarah dan Pembelajarannya, 2, Juli 2011).

Penting sekali pembinaan dasar yang harus diberikan kepada anak didik oleh para orang tua, guru dan masyarakat umum. Terutama yang menyangkut dengan masa depan mereka, kehidupan mereka harus ditanamkan nilai-nilai yang bagus sejak dini. bimbingan moral, akhlak dan perilaku dalam pergaulan dengan lingkungan sosial. Anak didik perlu diperkaya dengan siraman rohani, mereka harus senantiasa diawasi, memberikan bimbingan serta dorongan yang penuh ekstra agar mereka menjadi orang-orang yang bermartabat dan penuh dengan tata krama dalam mewarnai kehidupan dalam lingkungan sosial (Sulaiman, Serambi Tarbawi, 1, Januari 2013).

c. Thomas Aquinas

Persamaan Aquinas dengan Aristoteles adalah dalam kepercayaan tujuan pendidikan sebagai usaha mewujudkan kapasitas (potensial) yang ada di dalam individu agar menjadi aktif, dan nyata menjadi aktualitas. Peran guru terutama mengajar (to instruc) dalam arti memberi bantuan pada anak untuk berpikir jelas dan mampu mengerti hukum pertama secara intuitif (Syam, 1986: 322).

Thomas berpendapat bahwa pendidikan adalah menuntun kemampuankemampuan yang masih tidur menjadi aktif atau nyata tergantung pada kesadaran tiap-tiap individu. Seorang guru bertugas untuk menolong membangkitkan potensi yang masih tersembunyi dari anak agar menjadi aktif dan nyata. Aquinas menganalogikan fungsi guru sebagaimana fungsi seorang dokter. Dokter berfungsi membantu orang sakit agar sehat, sebab orang yang sakit punya kecenderungan sembuh dan sehat. Seperti itu pula, tugas seorang guru ialah membantu perkembangan prestasi-prestasi yang ada pada anak untuk berkembang. Kedua tugas 
itu, oleh dokter dan guru, tidak mungkin sukses tanpa adanya potensi yang sudah tertanam pada diri manusia.

Guru adalah orang-orang yang profesional, memiliki kemampuan dalam mendidik anak-anak. sebagai tugas utamanya mengajar, menggali potensi yang ada pada anak didik serta mengarah dan membina agar anak didik kelak menjadi manusia yang bernilai. Menurut J. Maritain, norma fundamental pendidikan adalah: cinta kebenaran, cinta kebaikan dan keadilan, kesederhanaan dan sifat terbuka terhadap eksistensi, cinta kerjasama.

Kaum perenialis juga percaya bahwa dunia alamiah dan hakikat manusia pada dasarnya tetap tidak berubah selama berabad-abad. Gagasan-gagasan besar terus memiliki potensi yang paling besar untuk memecahkan permasalahan-permasalahan di setiap zaman. Selain itu, filsafat perenialis lebih menekankan pada kemampuan berpikir rasional manusia sehingga hal tersebut yang membedakan antara mereka dengan binatang (Pelu, Jurnal Sejarah dan Pembelajarannya, 2, Juli 2011).

\section{Teori Belajar Perenialisme}

Teori atau konsep pendidikan perenialaisme dilatar belakangi oleh filsafat-filsafat plato sebagai Bapak Idealisme Klasik, filsafat Aristoteles sebagai Bapak Realisme Klasik, dan Filsafat Thomas Aquina yang mencoba memadukan antara filsafat Aristoteles dengan dengan ajaran Gereja Katolik yang tumbuh pada zamannya. Dengan demikian teori dasar dalam belajar menurut Perenialisme adalah:

a. Mental Disipline Sebagai Teori Dasar

Disiplin mental merupakan konsepsi Plato yang ditekankan secara berlebihan disekolah-sekolah abad pertengahan. Penganut perenialisme sependapat bahwa latihan dan pembinaan berpikir (mentaal disiplin) adalah salah satu kewajiban tertinggi dari belajar. Karenaitu teori dan program pendidikan pada umumnya dipusatkan pada pembinaan kemampuan berpikir (Syam, 1986: 325-328).

b. Rasionalitas dan Asas Kemerdekaan

Perenialisme menekankan prinsip utama bahwa manusia berbeda dengan makhluk lainnya yang tidak dapat dibedakan dengan sains melainkan dengan berpikir spekulatif, dengan filsafat. Perwujudan dan fungsi rasionalitas manusia adalah selfevident, bahwa seseorang tidak mungkin lagi melawan eksistensi rasio tanpa menggunakan rasio itu sendiri. Asas berpikir dan kemerdekaan harus menjadi tujuan utama pendidikan, otoritas berpikir harus disempurnakan sesempurna mungkin. Dan 
makna kemerdekaan adalah pendidikan adalah membantu manusia untuk menjadi dirinya sendiri, be him selfmenjadi esensial-selfyang membedakan dirinya dengan makhluk-makhluk lain. Sifat rasional pada manusia melahirkan konsep dasar tentang kebebasan. Bahwa dengan rasionya manusia dapat mencapai kebebasan dari belenggu kebodohan. Atas dasar itulah maka pandangan mengenai hal tersebut dapat disimpulkan bahwa belajar pada hakekatnya adalah belajar untuk berfikir, mengasah kemampuan yang dimilikinya. Untuk itu perlu diadakan kebiasaan-kebiasaan yang baik sejak anak didik masih muda.

c. Learning to Reason (belajar untuk Berpikir)

Perenialisme percaya dengan asas pembentukan kebiasaan dalam permulaan pendidikan anak, kecakapan membaca, menulis dan berhitung merupakan landasan dasar. Dan berdasarkan itu maka Learning to reason menjadi tujuan pokok pendidikan menengah dan pendidikan tinggi.

d. Belajar sebagai persiapan hidup

Belajar untuk mampu berpikir bukanlah semata-mata tujuan kebajikan moral dan kebajikan intelektual dalam rangka aktualitas sebagai filosofis. Belajar untuk berpikir berarti pula guna memenuhi fungsi practical philosophi baik etika, sosial politik, ilmu dan seni. Dan ini berarti memenuhi fungsi kehidupannya sebagai manusia.

e. Learning Trough Teaching

Fungsi guru menurut perenialisme adalah sebagai perantara antara bahan atau materi ajar dengan anak yang melakukan penyerapan. Menurut aliran perenialisme bukanlah perantara antara dunia dan jiwa anak, melainkan seorang guru juga sebagai murid yang mengalami proses belajar sementara mengajar. Guru mengembangkan potensi-potensi self-discovery dan ia melakukan otoritas moral atas murid-muridnya.

\section{Konsep Dasar Pandangan Aliran Perenialisme}

a. Pandangan Ontologi Perenialisme

Ontologi perenialisme terdiri dari pengertian seperti benda individual, esensi, aksiden dan substansi. Benda individual yang dimaksud di sini adalah benda yang dapat dilihat dan yang tampak di hadapan manusia serta dapat ditangkap dengan panca indra seperti batu, gunung, bangunan gedung, orang dalam ukuran, bentuk, warna, dan sedang melakukan aktivitas tertentu, seperti manusia yang ditinjau dari esensinya adalah sebagai makhluk berpikir. Sedangkan aksiden adalah keadaan khusus 
dimana sifatnya tidak terlalu penting misalnya orang yang suka berpakaian bagus. Dan substansi adalah suatu satu-kesatuan dari tiap-tiap hal individu yang khas dan universal, yang material dan spiritual (HW, 2013: 176).

b. Pandangan Epistemologis Perenialisme

Dalam filsafat perenialisme beracuan pada tiga istilah yang menjadi asas atau dasar di dalam epistemologi antara yaitu truth, self evidence, dan reasoning. Bagi perenialisme kebenaran adalah prasyarat untuk mengerti dan memahami arti realita semesta raya.Hubungan filsafat dan pengetahuan tetap diakui urgensinya, sebab analisa-empiris dan analisa ontologis keduanya dianggap perenialisme dapat komplementatif meskipun ilmu dan filsafat berkembang ke tingkat yang makin sempurna, namun tetap diakui bahwa fisafat lebih tinggi kedudukannya dari pada ilmu pengetahuan (Khobir, 2007: 62).

c. Pandangan Aksiologi Perenialisme

Pada aksiologi perenialisme, masalah nilai merupakan hal yang paling dasar dan paling utama, karena ia berdasarkan pada asas-asas supernatural yaitu dengan menerima kebenaran (truth) secara universal yang abadi, khususnya pada perbuatan dan tingkah laku manusia. Persoalan tentang nilai adalah persoalan yang berhubungan dengan spiritual juga karena manusiansecara alamiah condong pada kebaikan.

Pada hakikatnya, kepercayaan filsafat perenialisme adalah berpegang pada norma-norma atau nilai-nilai yang bersifat kekal atau abadi. Aliran filsafat perenialisme ini mengambil contoh atau analogi realita sosial budaya manusia seperti realita sepohon bunga yang terus menerus mekar dari musim ke musim, berubah warna secara tetap sepanjang masa dan dengan gejala yang terus ada dan sama (Khobir, 2007: 64).

d. Pandangan Aliran Perenialisme tentang Pendidikan

Perenialisme dalam konteks pendidikan dibangun atas dasar suatu keyakinan ontologisnya, bahwa batang tubuh pengetahuan yang berlangsung dalam ruang dan waktu ini mestilah terbentuk melalui dasar-dasar pendidikan yang diterima manusia dalam kesejahteraannya. Pendidikan menurut aliran ini adalah suatu upaya mempersiapkan kehidupan. Prinsip mendasar pendidikan bagi alira ini adalah membantu subjek-subjek didik menemukan dan menginternalisasikan kebenaran abadi, karena memang kebenarannya mengandung sifat universal dan tetap. Aliran ini 
meyakini bahwa pendidikan merupakan transfer ilmu pengetahuan mengenai kebenaran abadi.

Pengetahuan dapat dimaknai dengan suatu kebenaran, dan sedangkan kebenaran selamanya memiliki kesamaan. Sehingga penyelenggaraan pendidikan di mana-mana mestilah sama. Belajar adalah upaya dengan sungguh-sungguh dan dilakukan secara terus menerus untuk memperoleh suatu ilmu pengetahuan melalui disiplin tinggi dalam latihan untuk pengembangan prinsip-prinsip rasional dan potensi yang ada pada dirinya. Makna hakiki dari belajar merupakan belajar untuk berpikir. Dengan berpikir, peserta didik akan memiliki senjata ampuh atau dasar yang kuat dalam menghadapi berbagai rintangan yang dapat menurunkan martabat kemanusiaannya, seperti kebingungan, kebodohan, dan keragu-raguan dalam hidupnya (Muhmidayeli, 2011: 163-165).

Dapat disimpulkan bahwa pandangan perenialisme dalam pendidikan adalah pendidikan harus berdasarkan pada nilai-nilai luhur, norma-norma dan agama dan merupakan proses belajar mengajar yang harus dikembalikan pada nilai-nilai luhur, norma-norma, dan agama pada masa lalu. Pendidikan harus dapat melahirkan orangorang yang mematuhi norma dan istiqamah dijalan kebenaran. Pendidikan harus dipusatkan pada guru, karena guru memiliki kemampuan serta norma-norma dan nilai-nilai yang luhur. Maka dalam pandangan perenialisme, pendidikan anak usia dini sangatlah penting karena pada usia 0-6 tahun anak perlu diberikan rangsangan pendidikan dan pembelajaran agar potensi yang ada pada dirinya berkembang. Yang mana didalamnya juga perlu ditanamkan nilai-nilai luhur, norma-norma dan agama sehingga anak akan senantiasa berpegang teguh pada nilai-nilai yang telah tertanam pada dirinya dan harapannya anak senantiasa berperilaku dan memiliki karakter sesuai dengan nilai-nilai yang telah tertanam baik disekolah maupun ketika bermasyarakat dan berbangsa. Untuk mewujudkan pembelajaran yang akan diberikan kepada anak, yang mana menurut aliran filsafat penerialisme berupa pemberian dan penanaman nilai-nilai kebenaran, keabadian serta norma-norma agama tentu dalam pendidikan anak usia dini diperlukan kurikulum. Karena kurikulum adalah sebuah alat yang digunakan sebagai landasan, acuan, pegangan dalam pembelajaran serta memiliki peranan yang sangat penting terhadap seluruh kegiatan pendidikan yang mana dalam pengembangannya tidak lepas dari peranan aliran-aliran filsafat. 
Dalam sebuah pendidikan, tentu saja tidak bisa lepas dengan yang namanya unsur-unsur pendidikan. Unsur pendidikan adalah unsur yang harus ada dan sangat penting dalam sebuah pendidikan karena antara unsur yang satu dengan unsur yang lainnya memiliki keterkaitan dan tidak bisa terpisahkan. Unsur-unsur tersebut diantaranya adalah :

1) Tujuan Pendidikan

Filsafat perenialisme memandang bahwa tugas pendidikan adalah memberikan pengetahuan tentang norma-norma dan nilai-nilai kebenaran yang absolut, pasti, dan abadi dan terdapat dalam suatu kebudayaan masa lampau yang dipandang memiliki kebudayaan ideal. Bagi filsafat perenialis, norma-norma dan nilai-nilai kebenaran bersifat abadi dan universal maka hal tersebut yang harus menjadi tujuan dari pendidikan yang sejati. Sebab itu, tujuan pendidikannya adalah membantu peserta didik menyingkapkan dan menginternalisasikan nilai-nilai kebenaran yang abadi agar mencapai kebijakan dan kebaikan dalam hidup.

2) Metode Pendidikan

Perumusan pengertian metode biasanya disandingkan dengan teknik, dimana keduanya saling berhubungan. Metode pendidikanadalah prosedur umum dalam dalam penyampaian materi untuk mencapai tujuan pendidikan. Sedangkan teknik pendidikan adalah langkah-langkah konkret pada waktu seseorang melaksanakan pengajaran di kelas (Mujib, 2006: 166). latihan mental dalam bentuk diskusi, analisis buku melalui pembacaan buku-buku tergolong karya-karya besar, buku-buku besar tentang peradaban Barat.

Peranan guru bukan sebagai perantara antara dunia dan jiwa anak, melainkan guru juga sebagai "murid" yang mengalami proses belajar sementara mengajar. Guru mengembangkan potensi-potensi self-discovery. la juga melakukan moral authority (otoritas moral) atas murid-muridnya karena ia seorang profesional yang qualified dan superior dibandingkan dengan muridnya. Guru harus mempunyai aktualitas yang lebih, dan pengetahuan yang sempurna (HW, 2013: 174).

3) Peranan Guru dan Peserta Didik

Pelajar adalah makhluk rasional yang dibimbing oleh prinsip-prinsip pertama, kebenaran-kebenaran abadi, pikiran mengangkat dunia biologis. Guru memiliki peranan dominan dalam penyelenggaraan kegiatan belajar mengajar dikelas. Menurut perenialisme tugas guru bukanlah perantara antara dunia dan jiwa 
anak, melainkan guru juga sebagai murid yang mengalami proses belajar selama mengajar. Guru mengembangkan potensi-potensi self discovery dan ia melakukan moral authority atas murid-muridnya karena ia adalah seorang profesional. Filsafat pendidikan perenialisme mempunyai empat prinsip dalam pembelajaran secara umum yang harus dimiliki oleh manusia yaitu:

a) Kebenaran bersifat universal dan tidak tergantung pada tempat, waktu dan orang.

b) Pendidikan yang baik melibatkan pencarian pemahaman atas kebenaran.

c) Kebenaran dapat ditemukan dalam karya-karya agung.

d) Pendidikan adalah kegiatan yang bebas dilakukan untuk mengembangkan nalar (Alwasilah, 2008: 104).

\section{Perenialisme dan Kurikulum PAUD}

Kurikulum adalah seperangkat rencana yang telah disusun dan digunakan sebagai pegangan untuk mencapai tujuan dari pendidikan. Kurikulum adalah keseluruhan fasilitas, program, dan segala bentuk kegiatan dalam suatu lembaga pendidikan untuk mewujudkan visi dan misi dari lembaganya (Nasution, 1999: 8).

Kurikulum yang digunakan dalam perenialisme adalah yang berorientasi (subject centered) atau berpusat pada mata pelajaran. Bentuk kurikulum merupakan bentuk atau desain yang paling populer dan sering banyak digunakan dalam suatu lembaga pendidikan. Pada hakikatnya, kurikulum dalam lembaga pendidikan lebih dipusatkan pada isi/materi yang akan diajarkan (Hamalik, 2010: 17). Oleh karena itu materi pelajaran harus bersifat abadi dan selain itu materi pelajaran juga harus terarah kepada pembentukan nasionalitas manusia, sebab demikianlah hakikat manusia. Mata pelajaran yang mempunyai status tertinggi adalah mata pelajaran yang mempunyai "rational content" yang lebih besar.

Dalam sebuah lembaga pendidikan, secara umum isi atau materi pendidikan yang diajarkan adalah beberapa disiplin ilmu seperti: matematika, kesusasteraan, bahasa, dan humaniora, serta ilmu sejarah (Muammar, Nur El-Islam, 2, Okteber 2014: 15-28). Oleh sebab itu dalam suatu pendidikan, kurikulumnya harus memuat materi-materi yang sesuai potensi/fitrah peserta didik dan dapat mengembangkannya. Perenialisme membedakannya kurikulum sesuai dengan tingkatan pendidikan sebagai berikut:

1. Pendidikan Dasar 
Pendidikan dasar merupakan suatu upaya untuk mempersiapkan bagi kehidupan dalammasyarakat dengan menggunakan kurikulum utamanya yakni dengan membaca, menulis, dan menghitung atau dapat disingkat dengan calistung.

2. Pendidikan Menengah

Pada jenjang pendidikan menengah ini lebih menekankan adanya kurikulum tertentu yang digunakan sebagai latihan untuk berfikir seperti belajar bahasa asing, retorika, logikan dan lain sebagainya.

3. Pendidikan Tinggi atau Universitas

Untuk jenjang unversitas atau pendidikan tinggi ini adalah sebagai upaya lanjutan dari pendidikan menengah yang memiliki prinsip dasar untuk mengarahkan dan membawa peserta didik pada tujuan kebajikan intelektual "the intellectual love of God'. Dan menurut Hutchins, pada tingkatan ini diperlukan adanya sebuah lembaga penelitian.

\section{Pendidikan Orang Dewasa}

Pada jenjang ini bertujuan untuk meningkatkan pengetahuan yang telah dimilikinya dalam pendidikan sebelumnya. Nilai utama yang ditekankan pada pendidikan orang dewasa adalah mengembangkan dan mempraktikan sikap bijaksana agar orang dewasa dapat memerankan perannya sebagai pendidik bagai anak-anaknya. Serta sebagai jalan untuk mewariskan dan melestarikan kebudayaan yang dijunjung tinggi pada generasi sebelumnya (Syam, 1986: 329-333).

Dalam hal kurikulum, aliran ini menganggap hal yang paling dalam kurikulum adalah isi mata pelajaran yang tepat dan benar. Oleh karena kondisi demikian, maka dalam pendidikan peran utama dipegang oleh guru dan peserta didik. Keaktifan dan kreativitas subjek didik dikembangkan dengan besendikan atas pengetahuan dan keterampilan yang benar.

Pandangan perenialisme dalam pendidikan adalah pendidikan harus berdasarkan pada nilai-nilai luhur, norma-norma dan agama dan merupakan proses belajar mengajar yang harus dikembalikan pada nilai-nilai luhur, norma-norma dan agama pada masa lalu. Pendidikan harus dapat melahirkan orang-orang yang mematuhi norma dan istiqamah di jalan kebenaran. Pendidikan harus dipusatkan pada guru, karena guru memiliki kemampuan serta norma-norma dan nilai-nilai yang luhur.

Di samping itu, masih menurut aliran Perenialisme, pendidikan persekolahan diusahakan sama bagi setiap orang, di mana peserta didik diajak untuk menemukan 
kembali dan menginternalisasi kebenaran universal dan konstan dari masa lalu. Oleh karena itu metode yang digunakan dalam kurikulum model aliran Perenialisme ini adalah mengkaji terhadap buku-buku yang membahas peradaban Barat dan abad pertengahan melalui membaca dan diskusi untuk menyerap dan menguasai fakta-fakta dan informasi.

Anak usia dini adalah anak-anak yang berada dalam rentang usia 0-6. Batasan yang dipergunakan oleh the National Association For The Education Of Young Children (NAEYC) dan para ahli pada umumnya adalah "early childhood" anak masa awal adalah anak yang sejak lahir sampai usia delapan tahun. Jadi mulai dari anak lahir sampai umur enam tahun dikategorikan sebagai anak usia dini. Pada usia tersebut anak-anak masuk dalam masa keemasan atau dapat disebut dengan masa golden age. Masa tersebut adalah masa yang sangat penting bagi anak karena sangat menentukan dimasa berikutnya seperti apa mereka kelak jika dewasa baik kematangan dari segi fisik, mental maupun kecerdasan. Oleh karena itu peran orang tua dan pendidik sangatlah penting untuk memberikan stimulus kepada anak agar semua potensi yang ada pada dirinya berkembang sesuai harapan (Mulyasa, 2012: 16).

Kurikulum PAUD disusun agar dapat digunakan sebagai kerangka kerja (framework) yang berisi tentang rencana dan implementasi sebuah program kerja untuk mengembangkan segala aspek perkembangan maupun pertumbuhan dalam upaya menyiapkan anak untuk mencapai keberhasilan di sekolah maupun pada tahap selanjutnya. Oleh sebab itu kurikulum memegang peranan yang sangat penting serta memberikan pengalaman belajar yang menarik, bermakna, dan berkualitas.

Pendidikan anak usia dini (PAUD) merupakan pendidikan yang paling penting dan fundamental karena perkembangan anak di masa selanjutnya sangat ditentukan oleh berbagai stimulasi, contoh dari orang tua maupun pendidik yang diberikan sejak usia dini. oleh sebab itu pendidikan anak usia dini perlu dipersiapkan secara terencana dan bersifat holistik-integratif agar di masa emas perkembangannya, anak mendapatkan stimulasi yang utuh untuk mengembangkan berbagai potensi yang telah ada pada dirinya sejak lahir.

Upaya yang dapat dilakukan dalam upaya untuk pengembangan potensi yang ada pada diri anak tersebut dengan melalui program pendidikan yang telah tersusun secara terstruktur dalam kurikulumnya. Dengan adanya kurikulum dapat memudahkan dan memandu guru untuk memenuhi seluruh area belajar yang digunakan oleh anak atau peserta didik dengan memakai pendekatan pembelajaran yang tepat serta strategi 
penataan lingkungan yang sesuai guna mendukung berkembangnya potensi kemampuan yang dimiliki oleh anak sesuai dengan tahap pertumbuhan dan perkembangannya. Oleh sebab itu, maka seorang guru tentunya harus memiliki visi dan misi yang kuat tentang apa yang ingin dikembangkan pada anak didiknya berupa ilmu pengetahuan dan keterampilan yang dapat dipelajari anak, serta sikap yang akan ditanamkan pada anak sehingga menjadi bekal kelak di masa selanjutnya.

Kurikulum pendidikan anak usia dini bertujuan untuk mendorong perkembangan peserta didik secara optimal sehingga memberi dasar dan prinsip agar menjadi manusia yang memiliki kemampuan hidup sebagai pribadi yang inovatif, beriman, kreatif, produktif, dan afektif serta dapat memberikan kontribusi pada kehidupan bermasyarakat, berbangsa, bernegara, dan perdapan dunia (Susilo, 2007: 83). Kurikulum dapat diartikan sebagai langkah atau strategi yang disusun agar tercapainya tujuan dari sebuah pendidikan. Sedangkan tujuan dari pendidikan anak usia dini sendiri yaitu dapat membentuk anak didik yang berkualitas dalam artian anak yang dapat tumbuh dan berkembang sesuai dengan tingkat perkembangannya sehingga memiliki kesiapan yang optimal dalam memasuki pendidikan dasar serta dapat menghadapi segala resiko yang akan dihadapi pada kehidupan selanjutnya.

Sedangkan tujuan pendidikan perenialisme sendiri bertujuan memanusiakan manusia. Dalam konteks ini yang dimaksud memanusiakan manusia adalah menjadikan manusia yang bermoral memiliki akhlak yang baik serta beriman kepada Tuhannya. Dengan kata lain tujuan pendidikan perenialisme didasarkan pada nilai-nilai luhur, norma-norma, serta agama dan merupakan proses belajar mengajar yang harus dikembalikan pada nilai-nilai luhur, norma-norma, dan agama pada masa lalu. Pendidikan harus dapat melahirkan orang-orang yang mematuhi norma dan istiqamah dijalan kebenaran. Oleh karena itu dalam pendidikan anak usia dini menjadi pendidikan yang sangat utama dan pertama dalam menanamkan nilai-nilai atau norma kebaikan sehingga dapat melahirkan generasi yang dibanggakan.

Dari perbandingan antara tujuan kurikulum pendidikan anak usia dini dengan filsafat perenialisme dapat dikatakan bahwa keduanya cukup saling berkaitan. Menurut penulis, tujuan kurikulum dari sudut pandang perenialisme yakni membentuk pribadi seseorang yang menekankan pada nilai-nilai kebenaran, keabadian, serta pendidikan menjadi salah satu unsur yang sangat penting. Sedangkan kurikulum dalam pendidikan anak usia dini yakni bertujuan untuk membangun pengetahuan yang dimiliki anak, 
mengasah keterampilan yang ada pada diri anak, sehingga memiliki kesiapan untuk menuju kejenjang selanjutnya. Oleh sebab itu dapat ditarik kesimpulan bahwa tujuan kurikulum dilihat dari sudut pandang keduanya memiliki tujuan yang sama yakni membentuk manusia yang biasa mandiri dalam konteks kehidupan pribadinya, kehidupan bermasyarakat, berbangsa, dan bernegara serta berkehidupan sebagai makhluk yang berketuhanan Yang Maha Esa (beragama).

\section{Penutup}

Ada satu hal yang paling menonjol saat ini yang ditemukan dalam masyarakat adalah masalah moral. Masyarakat sekarang seolah-olah tidak lagi hidup dalam budaya dan nilainilai yang tertanam dalam masyarakat. Oleh karena itu, agar msyarakat sekarang terbentuk kembali sebagai masyarakat yang mempunyai budaya dan nilai-nilai leluhur perlu ditinjau kembali dalam dunia pendidikan. Pendidikan merupakah salah satu solusi untuk menata kehidupan masyarakat. Untuk memperbaiki tatanan kehidupan masyarakat saat ini yang penuh dengan kekacauan, maka perlu dilihat beberapa aspek yang terkait dengan pendidikan seperti tujuan pendidikan, metode pendidikan, isi kurikulum apakah sudah relevan kurikulum yang sudah ada dengan masa saat ini, disisi lain berkaitan dengan tenaga kependidikan yaitu guru, sarana dan unsur-unsur pendukung lainnya.

Kurikulum adalah suatu perangkat yang telah direncanakan sebagai uapaya atau pegangan untuk mencapai tujuan dari pendidikan. Kurukulum adalah kesuluhan program, fasilitas dan kegiatan dalam suatu lembaga pendidikan untuk mewujudkan visi dan misi lembaganya. Kurikulum yang digunakan dalam perenialisme adalah yang berorientasi (subject centered) atau berpusat pada nilai-nilai kebaikan dan keindahan yang ditanamkan. Dalam subject centered, kurikulum dipusatkan pada materi atau isi yang akan diajarkan kepada peserta didik. Pada hakikatnya, kurikulum PAUD digunakan sebagai kerangka kerja yang berisi segala rencana yang implementasikan pada sebuah program untuk mengembangkan segala aspek perkembangan yang ada pada diri anak yang digunakan dalam upaya menyiapkan anak didik dalam mencapai keberhasilan di sekolah maupun pada tahap selanjutnya. Filsafat perenialisme dalam kurikulum pendidikan anak usia dini yakni upaya membentuk karakter anak yang bermoral, menjunjung nilai-nilai luhur agama, dan senantiasa menjunjung tinggi nilai-nilai kebaikan diperlukan yang namanya pendidikan. Dalam sebuah pendidikan tentu saja diperlukan kurikulum yang dijadikan sebagai tolok 
ukur dalam sebuah pembelajaran karena hal tersebut sangatlah penting dan tidak bisa terpisahkan dalam sebuah pembelajaran

\section{Daftar Pustaka}

Alwasilah, Chaedar, 2008, Filsafat Bahasa dan Pendidikan, Bandung: PT. Remaja Rosdakarya.

Gandhi HW, Teguh Wangsa, 2013, Filsafat Pendidikan, Jogjakarta: Ar Ruzz Media.

Hamalik, Oemar, 2010, Kurikulum dan Pembelajaran, Jakarta: Bumi Aksara

Hidayat, Komaruddin dan Muhammad Wahyuni Nafis, 2003, Agama Masa Depan Perspektif

Filsafat Perenial, Jakarta: Gramedia Pustaka Utama.

Khobir, Abdul, 2007, Filsafat pendidikan Islam, Pekalongan: STAIN Pekalongan Press.

Muammar, M. Arfan, "Perenialisme Pendidikan (Analisis Konsep Filsafat Perenial dan Aplikasinya dalam Pendidikan Islam)," Nur El-Islam 1, no. 2 October 1, 2014.

Muhmidayeli, 2011, Filsafat Pendidikan, Bandung: Refika Aditama.

Mujib, Abdul, 2006, Ilmu Pendidikan Islam, Jakarta: Kencana.

Mulyasa, 2012, Manajemen PAUD, Bandung: Remaja Rosdakarya.

Nasution, S., 1999, Azas-Azas kurikulum, cet. 3 Jakarta:PT.Bumi Aksara

Pelu, Musa, "Lintasan Sejarah Filsafat Pendidikan Perenialisme dan Aktualisasinya," Agastya: Jurnal Sejarah dan Pembelajarannya 1, No. 2 (July 1, 2011).

Sadulloh, Uyoh, 2007, Pengantar Filsafat Pendidikan, Bandung: Alfabeta.

Sadulloh, Uyoh, 2012, Pengantar Filsafat Pendidikan, Bandung: Alfabeta.

Siregar, Raja Lottung, "Teori Belajar Perenialisme," Al-Hikmah: Jurnal Agama Dan Ilmu Pengetabuan 13, no. 2 (October 15, 2016): 83-172.

Sulaiman, "Pendidikan Versi Aliran Filsafat Perennialisme," Serambi Tarbawi 1, no. 1 (January 30, 2013).

Susilo, Muhammad Joko, 2007, Kurikulum Tingkat Satuan Pendidikan, Jogkarta: Pustaka Belajar.

Syam, Mohammad Noor, 1987, Filsafat Kependidikan dan Filsafat Kependidikan Pancasila, Surabaya: Usaha Nasional.

Zuhairini, 2001, Filsafat Pendidikan Islam, Jakarta: Bumi Aksara. 